\title{
Penambahan Bubuk Daun Cengkeh (Syzygium aromaticum) terhadap Kualitas Daging Broiler
}

\author{
The Added of Clover Powder (Syzygium aromaticum) to The Quality \\ of Broiler Meat
}

\author{
Astati*, Irmawaty, Amriana Hifizah, Nurjihan Islami Ansar, \\ Jurusan Ilmu Peternakan Fakultas Sains dan Teknologi \\ Universitas Islam NegeriAlauddin, Gowa-90245 \\ Sulawesi Selatan, Indonesia \\ *Korespondensi E-mail: astati@uin-alauddin.ac.id
}

\begin{abstract}
ABSTRAK
Penelitian ini bertujuan untuk mengetahui pengaruh pemberian pakan dengan penambahan bubuk daun cengkeh (Syzygium aromaticum) terhadap daging broiler. Penelitian menggunakan 45 ekor ayam umur 1 hari yang dipelihara selama 30 hari. Metode yang digunakan adalah Rancangan Acak Lengkap yang terdiri dari 5 perlakuan dan 3 ulangan dengan masing-masing perlakuan adalah $\mathrm{P}_{0}$ (kontrol), $\mathrm{P}_{1}$ (ransum basal+bubuk daun cengkeh 2\%), $\mathrm{P}_{2}$ (ransum basal+bubuk daun cengkeh 4\%), $\mathrm{P}_{3}$ (ransum basal+bubuk daun cengkeh 6\%), dan $\mathrm{P}_{4}$ (ransum basal+bubuk daun cengkeh $8 \%$ ). Hasil analisis menunjukkan bahwa pemberian pakan dengan penambahan bubuk daun cengkeh (Syzygium aromaticum) berpengaruh nyata $(\mathrm{P}<0,05)$ terhadap daya ikat air pada level $6 \%$ dan keempukan (daya putus daging masak) pada level 2, 4, dan 6\%, namun tidak berpengaruh nyata $(\mathrm{P}>0,05)$ terhadap susut masak dan $\mathrm{pH}$.
\end{abstract}

Kata kunci: Broiler, Bubuk Daun Cengkeh, Daya Ikat Air, Keempukan, pH, dan Susut Masak

\begin{abstract}
This research were aimed to determine the effect of feeding with the added of clove powder (Syzygium aromaticum) of broiler meat. Research using 40 of Day Old Chick (DOC) at one day old which were given fertilization 30 days. This study used a completely randomized design of 5 treatments and 3 replications consisted of $\mathrm{P}_{0}$ (control), $\mathrm{P}_{1}$ (basal feed $+2 \%$ clove powder), $\mathrm{P}_{2}$ (basal feed $+4 \%$ clove powder), $\mathrm{P}_{3}$ (basal feed+clove powder 6\%), and $\mathrm{P}_{3}$ (basal feed+clove powder $8 \%$ ). The parameters in this study are water holding capacity, cooking loss, tenderness, and $\mathrm{pH}$. The research showed that feeding with the added of clove powder (Syzygium aromaticum) at the level of $6 \%$ had a significant effect $(\mathrm{P}<0,05)$ to water holding capacity and tenderness (breaking power of cooked meat) at levels 2,4 , and $6 \%$, but did not significant affect $(\mathrm{P}>0,05)$ to cooking loss and $\mathrm{pH}$.
\end{abstract}

Keywors: Broiler, cooking loss, pH, Syzygium aromaticum, tenderness, water holoding capacity 


\section{PENDAHULUAN}

Pakan adalah semua makanan yang dimakan ternak yang mengandung nutrisi yang dapat memenuhi kebutuhannya yang dicerna oleh ternak dan tidak merusak pencernaan ternak. Pada pertumbuhan ayam, selain pakan yang menjadi makanan utama juga terdapat tambahan pakan untuk menunjang pertumbuhan dan mempengaruhi karakteristik dan kualitas daging.

Pengaruh pakan tambahan terhadap kualitas daging bervariasi dikarenakan ada faktor lain seperti umur, spesies, bangsa, jenis kelamin, bahan aditif, berat potong atau berat karkas, laju pertumbuhan, tipe ternak, dan perlakuan sebelum dan setelah pemotongan. Daging adalah produk pangan yang mudah rusak, kandungan dari gizi daging adalah media dari pertumbuhan mikroba. Kerusakan kualitas daging dapat terjadi akibat benturan fisik, perubahan kimia, dan aktivitas mikroba. Pertumbuhan dan aktivitas mikroba dipengaruhi oleh suhu penyimpanan, waktu, tersedianya oksigen, dan kadar air daging. Untuk menyeimbangkan penggunaan ransum dan membuat pertumbuhan lebih efisien, maka dapat ditambahkan bahan aditif yang bersifat alami dan aman seperti tumbuhan. Karena bahan aditif seperti antibiotik dapat menyebabkan residu yang berefek negatif bagi ternak maupun konsumen. Tanaman herbal seperti bubuk daun cengkeh (Syzygium aromaticum) yang sudah terbukti meningkatkan nafsu makan, dan salah satu penghasil minyak atsiri yang bisa menggantikan antibiotik.

Minyak atsiri dari cengkeh mempunyai sifat kimiawi dan efek farmakologis yang berfungsi sebagai anestetik, antimikrobial, antiseptik (Nurhidayati, 2013), antioksidan, dan imunomodulator (Dehgani et al, 2012). Senyawa fenolik daun cengkeh juga bertanggung jawab terhadap aktivitas antioksidan dan senyawa flavonoid yang bertindak sebagai penangkal radikal bebas (Dibazar et al, 2014). Senyawa flavonoid pada cengkeh dimanfaatkan untuk penangkal radikal bebas yang tersebar pada semua bagian tumbuhan baik pada akar, daun, kulit kayu, bunga, buah, ataupun bunga (Hanani, 2016). Antioksidan dalam senyawa flavonoid dapat membantu untuk memperbaiki kualitas daging seperti warna, bau serta menurunkan kadar kolesterol (Tugiyanti $d k k, 2014)$. 


\section{METODE}

\section{Prosedur Penelitian}

\section{Ternak dan Perlakuan Ternak}

Penelitian menggunakan 45 ekor Day Old Chick (DOC) yang dipelihara selama 1 bulan (30 hari). Penimbangan bobot badan dilakukan setiap minggu. Rancangan penelitian menggunakan Rancangan Acak Lengkap (RAL) yang terdiri dari 5 perlakuan dan 3 ulangan. Perlakuan yang digunakan dalam penelitian ini adalah:

$\mathrm{P}_{0}:$ Ransum dasar (kontrol)

$\mathrm{P}_{1}:$ Ransum dasar + bubuk daun cengkeh $2 \%$

$\mathrm{P}_{2}:$ Ransum dasar + bubuk daun cengkeh $4 \%$

$\mathrm{P}_{3}:$ Ransum dasar + bubuk daun cengkeh $6 \%$

$\mathrm{P}_{4}:$ Ransum dasar + bubuk daun cengkeh $8 \%$

Tabel 1. Komposisi Ransum Penelitian

\begin{tabular}{llllll}
\hline \multirow{2}{*}{ Jenis Pakan } & Perlakuan & & & \\
\cline { 2 - 6 } & $\mathbf{P}_{\mathbf{0}}$ & $\mathbf{P}_{\mathbf{1}}$ & $\mathbf{P}_{\mathbf{2}}$ & $\mathbf{P}_{\mathbf{3}}$ & $\mathbf{P}_{\mathbf{4}}$ \\
\hline Konsentrat (\%) & 100 & 100 & 100 & 100 & 100 \\
Bubuk daun cengkeh (\%) & 0 & 2 & 4 & 6 & 8 \\
\hline Total (\%) & 100 & 102 & 104 & 106 & 108 \\
\hline
\end{tabular}

\section{Pengelolaan Ternak dan Pemberian Pakan}

Sebelum Day Old Chick (DOC) dimasukkan ke dalam kandang, terlebih dahulu dilakukan sanitasi kandang dengan menggunakan desinfektan. 24 jam sebelum Day Old Chick (DOC) masuk ke dalam kandang, lampu kandang dinyalakan dengan tujuan menghangatkan ruang kandang. 45 ekor Day Old Chick (DOC) tersebut dilakukan penimbangan untuk mengetahui bobot badan awal. Day Old Chick (DOC) dimasukkan ke dalam kandang yang terdiri dari 15 petak kandang yang masing-masing berisi 3 ekor Day Old Chick (DOC). Setelah diistirahatkan selama 4 jam, Day Old Chick (DOC) diberikan air gula sebagai pengganti energi. 3 jam kemudian Day Old Chick (DOC) diberikan pakan dasar hingga umur 21 hari. Pada umur 22-30 hari broiler tersebut masih tetap diberikan pakan dasar dengan penambahan bubuk daun cengkeh. Bubuk daun cengkeh (Syzygium aromaticum) diperoleh dari pengeringan dengan oven pada suhu 40-50 ${ }^{\circ} \mathrm{C}$ selama 72 jam, 
kemudian daun cengkeh diperkecil partikelnya (diremas dengan tangan) agar saat penepungan lebih mudah. Pakan yang diberikan adalah pakan komersial B $11-\mathrm{A}$. Air minum ditambahkan vitachick yang diberikan secara ad libitum mulai hari pertama hingga panen (30 hari).

Tabel 2. Kandungan Nutrisi Pakan Komersial $B_{11}-A$

\begin{tabular}{ll}
\hline Nutrisi Pakan & Kandungan \\
\hline Protein (\%) & $22,0-23,5 \%$ \\
Serat Kasar (\%) & $5,0 \%$ \\
Calsium (\%) & $0,9 \%$ \\
Pospor (\%) & $0,60 \%$ \\
Aflatoxin & Max $50 \mathrm{ppb}$ \\
Lisin & Min $1,20 \%$ \\
Metionin & Min $0,45 \%$ \\
Met+Sistin & Min $0,80 \%$ \\
Triftofan & Min $0,19 \%$ \\
Treonin & Min $0,75 \%$ \\
\hline
\end{tabular}

\section{Parameter yang Diukur}

Parameter yang diukur dalam penelitian ini adalah:

1. Daya Ikat Air (DIA)

Pengukuran Daya Ikat Air dihitung dengan menggunakan rumus:

Daya Ikat Air $=\%$ Kadar Air $-\frac{\mathrm{mgH} 20}{300} \times 100$

2. Susut Masak

Pengukuran Susut Masak dihitung dengan menggunakan rumus:

Susut Masak $=\frac{\text { Berat sebelum pemasakan }- \text { Berat setelah pemasakan }}{\text { Berat sebelum pemasakan }} \times 100 \%$

3. Keempukan

Pengukuran Keempukan dihitung dengan menggunakan rumus:

Keempukan $(\mathrm{mm} / \mathrm{g} / 10$ detik $)=\frac{\text { Rata }- \text { rata pengukuran }}{10 \text { detik }}$

4. $\mathrm{pH}$

Pengukuran $\mathrm{pH}$ dengan menggunakan $\mathrm{pH}$ meter 


\section{Analisis Data}

Untuk mengetahui pengaruh pemberian bubuk daun cengkeh terhadap kualitas daging broiler digunakan Analisis Sidik Ragam sesuai dengan Rancangan Acak Lengkap (RAL) dan perlakuan yang memperlihatkan pengaruh nyata diuji lebih lanjut dengan menggunakan Uji BNT (Beda Nyata Terkecil) dengan model matematik:

$\mathrm{Y}_{\mathrm{ij}}=\mu+\mathrm{T}_{\mathrm{i}}+\varepsilon_{\mathrm{ij}}$

Dimana:

$\mathrm{Y}_{\mathrm{ij}} \quad=\quad$ Hasil Pengamatan dari peubah pada penggunaan bubuk daun cengkeh

$\mu \quad=\quad$ Rata-rata pengamatan

Eij $\quad=\quad$ Pengaruh perlakuan ${ }_{\mathrm{i}}$

$\mathrm{T}_{\mathrm{i}} \quad=\quad$ Error/galat perlakuan ke-i dan ulangan ke- ${ }_{-j}$

\begin{tabular}{|c|c|c|}
\hline $\operatorname{BNT}_{(0,05)}$ & $=$ & $\mathrm{t}_{0,05} \mathrm{~s} \hat{\mathrm{Y}}_{\mathrm{i}}$ \\
\hline $\operatorname{BNT}_{(0,01)}$ & $=$ & $\mathrm{t}_{0,01} \mathrm{~s} \hat{\mathrm{Y}}_{\mathrm{i}-}$ \\
\hline & & $\mathrm{T} \alpha\left(2 \mathrm{~s}^{2} / \mathrm{r}\right)$ \\
\hline
\end{tabular}

Keterangan:

$\begin{array}{lll}\mathrm{BNT} & = & \text { Nilai tengah perlakuan dengan kombinasi pada taraf } 2 \% / 8 \% \\ \mathrm{~T} \alpha & = & \text { Nilai derajat bebas galat pada tabel } \mathrm{x}^{2} \\ \mathrm{~s}^{2} & = & \text { Nilai kuadrat tengah galat }(\mathrm{KTG}) \\ \mathrm{R} & = & \text { Ulangan }\end{array}$

\section{HASIL DAN PEMBAHASAN}

Hasil penelitian pengaruh pemberian pakan dengan penambahan bubuk daun cengkeh (Syzygium aromaticum) terhadap kualitas daging broiler disajikan pada Tabel 3.

Tabel 3. Rataan Hasil Pengukuran Pengaruh Pemberian Pakan dengan Penambahan Bubuk Daun Cengkeh (Syzygium aromaticum) terhadap Kualitas Daging Broiler

\begin{tabular}{llllll}
\hline Parameter & \multicolumn{5}{c}{ Perlakuan } \\
\cline { 2 - 6 } & \multicolumn{1}{c}{$\mathbf{P}_{\mathbf{0}}$} & \multicolumn{1}{c}{$\mathbf{P}_{\mathbf{1}}$} & \multicolumn{1}{c}{$\mathbf{P}_{\mathbf{2}}$} & \multicolumn{1}{c}{$\mathbf{P}_{\mathbf{3}}$} & $\mathbf{P}_{\mathbf{4}}$ \\
\hline Daya Ikat Air & $34,40 \pm 05,27^{\mathrm{a}}$ & $23,13 \pm 3,94^{\mathrm{b}}$ & $28,07 \pm 6,40^{\mathrm{c}}$ & $33,31 \pm 3,16^{\mathrm{d}}$ & $21,78 \pm 1,22^{\mathrm{a}}$ \\
Susut Masak & $9,58 \pm 0,74$ & $11,55 \pm 1,59$ & $12,06 \pm 2,65$ & $12,06 \pm 2,65$ & $11,64 \pm 1,03$ \\
Keempukan & $0,40 \pm 0,04^{\mathrm{a}}$ & $0,56 \pm 0,15^{\mathrm{b}}$ & $0,56 \pm 0,01^{\mathrm{b}}$ & $0,63 \pm 0,05^{\mathrm{c}}$ & $0,85 \pm 0,09^{\mathrm{d}}$ \\
pH & $6,38 \pm 0,12$ & $6,27 \pm 0,09$ & $6,31 \pm 0,04$ & $6,32 \pm 0,13$ & $6,28 \pm 0,07$ \\
\hline
\end{tabular}

Keterangan: Superskrip yang berbeda pada baris yang sama menunjukkan perbedaan yang nyata $(\mathrm{P}<0,05)$. 


\section{Daya Ikat Air}

Nilai rataan tertinggi daya ikat air dengan penambahan bubuk daun cengkeh (Syzygium aromaticum) terhadap pakan terdapat pada perlakuan $\mathrm{P}_{3}(33,31)$, dan analisis sidik ragam menunjukkan bahwa nilai daya ikat air berpengaruh nyata $(P<0,05)$ terhadap kualitas daging broiler.

Hasil uji lanjut BNT menunjukkan bahwa setiap perlakuan memperlihatkan perbedaan yang nyata terhadap kemampuan mengikat air pada daging broiler, yaitu antara perlakuan $\mathrm{P}_{0}$ berbeda dengan $\mathrm{P}_{1}, \mathrm{P}_{2}$, dan $\mathrm{P}_{3}$. Sementara pada perlakuan $\mathrm{P}_{1}$ berbeda dengan $\mathrm{P}_{2}$ dan $\mathrm{P}_{3}$. Perlakuan $\mathrm{P}_{2}$ berbeda dengan $\mathrm{P}_{3}$. Hal ini memberikan indikasi bahwa semakin tinggi penggunaan bubuk daun cengkeh (Syzygium aromaticum), maka semakin baik nilai gizi pada daging terutama protein. Peningkatan protein dalam daging dapat mempengaruhi kemampuan mengikat air pada daging. Semakin tinggi kadar protein daging, maka kemampuan menahan air pada daging juga tinggi. Hal ini sesuai dengan pendapat Pratama (2015), yang menyatakan bahwa daya ikat air berhubungan dengan protein karena molekulmolekul air bebas berjumlah sekitar $10 \%$ terikat di antara molekul protein dan akan menurun bila protein daging mengalami denaturasi.

\section{Susut Masak}

Kualitas daging broiler dengan pemberian pakan dengan penambahan bubuk daun cengkeh (Syzygium aromaticum) menunjukkan rataan susut masak tertinggi pada perlakuan $\mathrm{P}_{3}(12,79)$. Analisis sidik ragam menunjukkan bahwa nilai susut masak pada daging ayam broiler yang diberikan pakan dengan penambahan bubuk daun cengkeh (Syzygium aromaticum) tidak berpengaruh nyata $(\mathrm{P}>0,05)$. Hal ini menunjukkan bahwa kandungan bubuk daun cengkeh (Syzygium aromaticum) berperan dalam mengikat nutrisi pada daging broiler saat pemasakan. Sebagaimana Pratama dkk., (2015) menjelaskan bahwa, daging yang memiliki susut masak rendah mempunyai kualitas daging yang baik karena nutrisi gizi yang hilang lebih sedikit. Daging dengan susut masak lebih rendah mempunyai kualias relatif lebih baik dari pada daging dengan susut masak lebih tinggi.

\section{Keempukan}

Kualitas daging broiler yang diberikan pakan dengan penambahan bubuk daun cengkeh (Syzygium aromaticum) menunjukkan rataan keempukan (daya putus daging masak) 
tertinggi pada perlakuan $\mathrm{P}_{4}(0,85)$. Berdasarkan analisis sidik ragam, nilai keempukan (daya putus daging masak) pada daging broiler yang diberikan pakan dengan penambahan bubuk daun cengkeh menunjukkan pengaruh yang nyata $(\mathrm{P}<0,05)$. Hal ini disebabkan karena bubuk daun cengkeh mempengaruhi penyusun otot pada daging broiler.

Hasil uji lanjut BNT menunjukkan bahwa penggunaan bubuk daun cengkeh menunjukkan perbedaan yang pa nyata terhadap keempukan daging broiler, yaitu antara perlakuan $\mathrm{P}_{0}$ berbeda dengan $\mathrm{P}_{1}, \mathrm{P}_{2}, \mathrm{P}_{3}$, dan $\mathrm{P}_{4}$. Sementara pada perlakuan $\mathrm{P}_{1}$ dan $\mathrm{P}_{2}$ berbeda dengan $\mathrm{P}_{3}$ dan $\mathrm{P}_{4}$. Perlakuan $\mathrm{P}_{3}$ berbeda dengan $\mathrm{P}_{4}$. Menurut Hartono dkk (2013), bahwa semakin tinggi nilai daya putus daging suatu sampel daging maka semakin tinggi pula nilai kealotannya atau keempukannya sebaliknya jika nilai daya putus daging rendah maka dapat menghasilkan daging yang empuk atau tingkat keempukannya tinggi. Dan menurut Soeparno (2015), keempukan daging merupakan suatu karakteristik kualitas yang kompleks yang dipengaruhi oleh banyak faktor. Faktor yang mempengaruhi keempukan daging digolongkan menjadi faktor antemortem seperti genetik termasuk bangsa, spesies dan fisiologi, umur, manajemen, jenis kelamin dan stress dan faktor postmortem yang meliputi metode chilling, refrigerasi, pelayuan dan pembekuan termasuk faktor biokimia sebelum dan setelah penyembelihan.

$\mathrm{pH}$

Kualitas daging broiler dengan penambahan bubuk daun cengkeh (Syzygium aromaticum) menunjukkan rataan tertinggi pada perlakuan $\mathrm{P}_{3}$ (6,32). Analisis sidik ragam menunjukkan bahwa nilai $\mathrm{pH}$ pada daging broiler yang diberikan pakan dengan penambahan bubuk daun cengkeh (Syzygium aromaticum) tidak berpengaruh nyata ( $\mathrm{P}>0,05)$. Hal ini disebabkan pemberian bubuk daun cengkeh (Syzygium aromaticum) pada pakan masih pada tahap normal, dimana bubuk daun cengkeh (Syzygium aromaticum) yang digunakan tidak cukup kuat peranannya dalam meningkatkan $\mathrm{pH}$ daging. Hal ini sesuai dengan pendapat Soeparno (2009), bahwa faktor pH daging juga dipengaruhi salah satunya adalah pakan. Pakan yang diberi campuran bubuk daun cengkeh (Syzygium aromaticum) dapat menormalkan $\mathrm{pH}$ pada daging, yang mana bubuk daun cengkeh (Syzygium aromaticum) banyak terdapat kandungan seperti anastetik, antimikrobial, antiseptik, dan antioksidan.

Kandungan senyawa antioksidan yang ada pada bubuk daun cengkeh dapat memperlambat peningkatan nilai $\mathrm{pH}$ yang dapat berpengaruh pada kualitas daging yang 
dihasilkan. Sebagaimana yang dilaporkan oleh Nurhidayati dan Sulistiowati (2013), bahwa minyak atsiri dari cengkeh mempunyai sifat kimiawi dan efek farmakologis yang berfungsi sebagai anastetik, antimikrobial, dan antiseptik.

\section{KESIMPULAN}

Berdasarkan hasil dan pembahasan bahwa pemberian pakan dengan penambahan bubuk daun cengkeh (Syzygium aromaticum) pada level 6\% berpengaruh nyata terhadap daya ikat air dan keempukan (daya putus daging masak) pada level 2, 4, dan 6\%), namun tidak berpengaruh nyata terhadap susut masak dan $\mathrm{pH}$.

\section{DAFTAR PUSTAKA}

Dehghani, F., Heshmatpour, A., Panjehshahin, M.R. and Khozani, T.T. 2012. Toxic effects of water/alcoholic extract of syzygium aromaticum on sperm quality, sex hormones and reproductive tissues in male mouse. IUFS J Biol, 71 (2): 95 - 102.

Dibazar, S.P., Fateh, S., dan Daneshmandi, S. 2014. Clove (Syzigium aromaticum) ingredients affect lymphocyte subtypes expansion and cytokine profile responses: an in vitro evaluation. Food and drug analysis, 22:448454.

Hanani, E. 2016. Analisis Fitokimia. Buku Kedokteran EGC, Jakarta.

Hartono, E., Iriyanti, N., dan Santoso, S.S. 2013. Penggunaan pakan fungsional terhadap daya ikat air, susut masak dan keempukan daging ayam broiler. JIP.1(1):10-19.

Nurhidayati, L., dan Sulistiowati. 2013. Penetapan Kadar Eugenol dalam Minyak Atsiri dari Tiga Varietas Bunga Cengkeh (Syzygium Aromaticum(L) secara Kromatografi Gas. Seminar Nasional dalam Rangka Lustrum X. Fakultas Farmasi. Universitas Pancasila, Jakarta.

Pratama, A., Suradi, K., I R., Belia., Chairunnisa, H., Lengkey A.H.W., Sutardjo, D.S., Suryaningsih, L., Gumilar, J., Wulandari, E., dan Putranto, W.S. 2015. Evaluasi karakteristik sifat fisik karkas ayam broiler berdasarkan bobot badan hidup. Jurnal Ilmu Ternak, 15 (2), 61-64.

Soeparno. 2009. Ilmu dan Teknologi Daging. Cetakan Kelima. Gadjah Mada University Press, Yogyakarta.

. 2015. Ilmu dan Teknologi Daging. Cetakan Keenam (Edisi Revisi). Gadjah Mada University Press, Yogyakarta.

Tugiyanti, E, Yuwanta, T., Zuprizal dan Rusman. 2014. Supplementation of vitamin E and C in feed on meat quality, thiobarbituric acid reactive substance (tbars) and myoglobinlevel of muscovy duck meat. J Indonesian Trop Anim Agric, 39(1),37-44. 